\title{
Determination of Capital Structure of Public Companies in Indonesia
}

\author{
Anita Handayani \\ University Of Muhammadiyah Gresik, Indonesia \\ E-mail: anita.handayani@umg.c.id \\ Rahmat Agus Santoso \\ University Of Muhammadiyah Gresik, Indonesia \\ E-mail: ra_santoso@umg.ac.id
}

Received: August 3, 2019 Accepted: September 10, 2019 Published: September 12, 2019

doi: 10.5296/jsss.v7i1.15210 URL: https://doi.org/10.5296/jsss.v7i1.15210

\begin{abstract}
Capital structure is definitely related to the company's long-term expenditure. Capital structure compares long-term debt to own capital. Corporate funding policies can be obtained from internal and / or external companies. So the purpose of this study is to analyze the capital structure of public companies in Indonesia. In the process of determining capital structure determination using multiple linear regression statistics, the results of the study are Return On Assets, Total Asset Turnover, and Current Ratio have a negative influence on the capital structure of public companies in Indonesia. So it can be concluded that public companies in Indonesia use internal funds more than external capital because internal capital does not create a fixed burden for the company.
\end{abstract}

Keywords: Capital structure, Return on assets, Total asset turnover, Current ratio

\section{Introduction}

Corporate funding policy is a policy about the use of funds originating from internal or external sources. This is usually called the capital structure, which is a policy about the proportion of debt usage and own capital in the company's operations. This is usually called the company's capital structure. For public companies this capital structure decision is very important, because it can directly affect the company's finances, and the capital structure can be influenced by several factors such as profitability, liquidity and activity. Decision on capital 
structure can affect the risks borne by shareholders, but also in tandem with the level of profits received by shareholders. The impact of capital structure decisions made by financial managers can have an impact on the company's financial risks where if the company is unable to pay its obligations, financial difficulties can occur to the company. The purpose of this study is to prove empirically the factors that can affect the company's capital structure public companies in Indonesia.

\subsection{Capital Structure}

The company's capital structure is a funding policy regarding the balance between long-term debt and own capital (Riyanto, 2010: 22). Therefore, a balance between the use of these two sources of funds is needed. The company's capital structure can be formulated as follows: Capital structure $=$ Longterm Debt $/$ Equity

The theories related to the capital structure of the company are as follows (Sudana, 2015: 172):

1) Trade Off Theory

The theory Trade Off describes the savings of taxes and bankruptcy costs obtained from the use of debt. The meaning is that when a company uses large amounts of debt initially it will increase the value of the company, the impact of tax savings is greater than the cost of bankruptcy.

2) Signaling Theory

This signal theory suggests how companies give signals to the users of financial statements, because this theory shows information imbalance / information asymmetry between company management and those who need the financial statements. Based on signal theory, companies that have a lot of profits will tend to use more debt. (Sudana, 2015: 174).

\section{3) Pecking Order Theory}

The Pecking Order theory states that there are several uses of funds by companies. Initially the company will use the company's internal funds in the form of retained earnings, if internal funds are not enough, the company uses external funds in the form of debt then issues new shares. From the selected external funds, it is debt in advance because the cost of capital is cheaper than the issuance of new shares. (Myers, 1984)

\section{4) Agency Theory}

Basically every company is managed by company management. Company management consists of people who run company activities. In this theory states that managers have personal goals that conflict with the aim to maximize the wealth of company shareholders, so that this can lead to conflict between managers and company shareholders. In addition, conflicts also arise between managers and creditors.

\subsection{Factors That Influence Capital Structure}

Capital tructure is the composition of corporate funding with long-term debt with own capital. Determination of the composition of long-term debt with own capital can be influenced by several factors, among others: According to Bambang Riyanto (2001: 296) capital structure can be influenced by interest rates, income stability, asset structure, asset risk level, amount of capital needed, capital market conditions, the nature of management and the size of a company. According to Margaretha (2010: 120) capital structure can be influenced by growth, size, 
tangibility, profitability, liquidity, non debt tax shields, age and investment. Some of the factors above are factors that influence the company's capital structure, in this study will examine several factors, namely company age, company size, tangibility, profitability, liquidity, and business risk.

Return On Assets (ROA) is the company's ability to generate profits by utilizing assets owned by the company (Sudana, 2011: 22). Companies with high levels of profitability will tend to carry out operational activities by using internal capital rather than external funds. Pecking order theory also shows that companies are profitable, funding tends to come from internal funds. From these theories can indicate that return on assets affect the capital structure. In accordance with Farisa and Widati (2017) which states that return on assets has a significant negative effect on capital structure.

H1 : There is an effect of Return On Asset on Capital Structure

Current Ratio (CR) is one measurement of the liquidity ratio that is used to determine the company's ability to pay its short-term debt using current assets owned (Kasmir, 2012: 134). Companies with high levels of liquidity will prefer to use internal funds compared to external funds to finance new investments. Pecking orders explain that companies are more likely to choose to fund companies with internal funds, so this theory predicts a negative relationship between liquidity and capital structure. In accordance with Riasita (2014) which states that Current Ratio has a significant negative effect on Debt to Equity Ratio.

\section{$\mathrm{H} 2$ : There is the influence of Current Ratio on Capital Structure}

Total Asset Turn Over (TATO) is a ratio to measure the effectiveness of total asset use in generating sales volume to generate profits (Hanafi \& Halim, 2009: 81)Total Asset Turnover (TATO) is a ratio to measure the effectiveness of total asset use in generating sales volumes to generate profits (Hanafi \& Halim, 2010: 81). Companies that have a large TATO value show that a company's assets can spin faster and generate profits and more efficiently use the entire asset in generating sales. The profits obtained by the company will be used as capital for other operational and financing activities. This shows that total asset turnover affects the capital structure. Watung (2016) shows that TATO (Total Asset Turn Over) affects the capital structure.

H3 : There is an effect of Total Asset Turnover on Capital Structure

\section{Methodology}

According to Malhotra (2005: 89) there are two research studies exploratory and conclusive. Explorative research is used to get an overview and understanding of the problem to be studied, while conclusive research is research designed to make decisions in determining, evaluating, and choosing a series of actions to be taken in certain situations. Conclusive research is divided into two, namely descriptive and causal. Descriptive research is a conclusive study that has the aim to describe a characteristic, while causal research is research whose main purpose is to obtain evidence regarding causal relationships. Based on this theory, this research used quantitative method.

According to Usman (2006: 181) the population is certain characteristics of a group of objects that are complete and clear, both the results of calculations and measurements can quantitative and qualitative. The population used in this study is a company listed on the Indonesia Stock 
Exchange. Soeratno and Arsyad (2003: 105) said that the sample is the real part of a study. The sample technique used in this study was purposive sampling with the following criteria Companies listed on the Stock Exchange in 2015-2017 and have positive profits in 2015-2017.

This research has two types of variables consisting of independent variables, namely the capital structure of the company and the dependent variable (Dependent Variable), namely profitability (Return On Assets), liquidity (Current Ratio) and Activity (Total Asset Turnover). The types of data are secondary data, data obtained by collecting tie sources that already exist. Data source in this study were obtained from www.idx.co.id.. Data collection techniques use the documentation method. According to Arikunto (2006: 234) the documentation method is a method of data collection carried out by taking, quoting, and studying documents - documents relating to the research. Documentation method through collecting financial statement data (balance sheet and profit / loss report) which is then processed and analyzed quantitatively.

analysis techniques used in this study are multiple regression. The general linear multiple regression equation can be formulated as follows (Ghozali, 2013: 13):

$\mathrm{Y}=\mathrm{a}+\mathrm{bX} \mathrm{X}_{1}+\mathrm{bX} \mathrm{X}_{2}+\mathrm{bX} \mathrm{X}_{3}+\mathrm{e}$

Description

$\mathrm{Y} \quad=$ Dependent variables

$\mathrm{X}_{1,2,3}=$ Independent variable $(1=\mathrm{ROA}, 2=\mathrm{CR}, 3=\mathrm{TATO})$

a $\quad=$ constant

$\mathrm{b}_{1,2,3}=$ Regression coefficient

$\mathrm{e} \quad=$ error standard

The coefficient of determination $\left(\mathrm{R}^{2}\right)$ is done to test how far the ability of the model to explain the variation of the dependent variable. The coefficient of determination is between one and zero. If the $\mathrm{R}$ value small it means that the ability of the independent variables is very limited in explaining the variation of the dependent variable. If the resulting value approaches one then the independent variables provide almost all the information needed to predict the variation of the dependent variable.

\section{Result and Discussion}

\subsection{Normality Test}

Normality test is done to test whether the regression model on the residual variable has a normal distribution or not. Normality tes use the non-parametric statistical test Kolmogorov-Smirnov (KS). Data is normally distributed if the significance value is above 0.05 . And the data is said to be abnormal if the significance value is below 0.05 .

\subsection{Multicollinearity Test}

The multicollinearity test is conducted to see whether there is a correlation to the independent variable. Regression models should not have a correlation between independent variables. The occurrence of Multicollinearity according to Ghozali (2013: 105) can be seen from the value tolerance and variance inflation factor (VIF). The multicollinearity test in this study by using the basis of decision making with a value of Tolerance $>0.10$ or the same as the VIF value $<10$, the model can be said to be free from Multicollinearity 


\subsection{Autocorrelation Test}

Autocorrelation test aims to see whether there is a correlation in the regression model between disruptive errors in period $t$ and the interruption of the previous period $t$ (Ghozali, 2013: 110). To test autocorrelation can use Durbin-Watson (DW Test). Decision-making occurrence of autocorrelation is as follows:

Table 1. Decision autocorrelation

\begin{tabular}{lll}
\hline null hypothesis & Decisions & If \\
\hline No positive autocorrelation & Decline & $0<\mathrm{d}<\mathrm{dl}$ \\
No positive autocorrelation & No decision & $\mathrm{d} l \leq \mathrm{d} \leq \mathrm{du}$ \\
Nothing negative correlation & Reject & $4-\mathrm{dl}<\mathrm{d}$ \\
$<4$ there is a negative correlation & No decision & $4-\mathrm{du} \leq \mathrm{d} \leq 4-\mathrm{dl}$ \\
No autocorrelation, positive or negative & Not rejected & $<\mathrm{d}<4-\mathrm{du}$ \\
\hline
\end{tabular}

\subsection{Heteroscedasticity Test}

The heteroscedasticity test in this study uses the glejser test which regresses the residual absolute value against the independent variable (Ghozali, 2013: 142). If the statistically significant independent variables affect the dependent variable Ut Absolute Value (AbsUt), heteroscedasticity will occur. There will be no indication of heteroscedasticity if the probability of the significance level is above the confidence level of $5 \%$ or 0.05 .

\subsection{Hypothesis Testing}

Hypothesis Testing aims to analyze and draw conclusions on the problems under study so that it can be decided whether to reject or accept the hypothesis. In this study, hypothesis testing is determined by a partial test or $\mathrm{t}$ test and test simultaneously or $\mathrm{F}$ test.. This research using data from all companies in the Indonesia Stock Exchange (IDX) with a period of three years from 2015 until 2017. The number of companies listed on the Indonesia Stock Exchange (IDX) in the period 2015 to 2017 were 504 companies. The data used in the research are annual financial reports. Of the number of companies listed on the Indonesia Stock Exchange in 2015-2017 as many as 504 companies, there are many companies that do not meet the research criteria so that the number of companies that make up the population in this study is only 40 companies. This research was conducted for three years so that the sample in this study was 120 companies. However, because the data is not normally distributed, autocorrelation occurs, and heteroscedasticity occurs, the researcher transforms the data by removing 48 outliers. So that the sample obtained is 72 data.

\subsection{The Normality Test}

The result of the Kolmogorov-Smirnov (KS) test on company data listed on the Indonesia Stock Exchange in 2015-2017 
Table 2. Test Results Kolmogrov-Smirnov (KS)

\section{Kolmogorov-Smirnov One-SampleTest}

Unstandardized Residual

Asymp. Sig. (2-tailed)

a. The distribution test is Normal.

Source: SPSS Output Results.

Normality test using the Kolmogorov-Smirnovtest (KS) show that the value of Asymp. Sig. (2-tailed) must be more than 0.05 for normal distribution data. In table 2 the value of Asymp. Sig. (2-tailed) for data from companies listed on the Indonesia Stock Exchange in 2015-2017 amounting to 0.200 and exceeding the significant level that has been determined which is 0.05 so that the data can be said to be normally distributed.

\subsection{Multicolinearity Test}

Table 3. Multicolinearity Test Result

\section{Coefficients $^{\mathrm{a}}$}

Model

Collinearity Statistics

Tolerance

VIF

1 (Constant)

$\begin{array}{lll}\text { LN_ROA } & .796 & 1.256 \\ \text { LN_CR } & .874 & 1.145 \\ \text { LN_TATO } & .885 & 1.130\end{array}$

a. Dependent Variable: LN_DER

Source: SPSS Output Results.

Based on the results of SPSS output in table 3, the value tolerance for the three variables is greater than 0.10, namely Return On Assets (X1) variable of 0.796, Current Ratio (X2) variable is 0.874 and variable TotalAsset Turnover (X3) of 0.885 . The VIF value of the three variables also shows results that are smaller than 10, namely the Return On Assets (X1) variable has a VIF value of 1.256, the Current Ratio (X2) variable is 1.145 and the variable is Total Asset Turnover (X3)1.130. Then it can be concluded that the value of Tolerance Value $>0.10$ and VIF $<10$ which means that the variables used do not have problems in the multicollinearity test.

\subsection{Autocorrelation Test}

The output of the autocorrelation test from the variables Return On Assets (X1), Current Ratio (X2), Total Asset Turnover (X3) and Debt to Equity Ratio (Y)on companies listed on the Indonesia Stock Exchange in 2015-2017 : 
Table 3. Autocorrelation Test Results

\begin{tabular}{ll}
\hline Summary $^{\mathbf{b}}$ & Durbin-Watson \\
\hline Model & 1.766 \\
1 & \\
a. Predictors: (Constant), LN_TATO, LN_CR, LN_ROA \\
b. Dependent Variable: LN_DER
\end{tabular}

Source: SPSS Output Results.

Based on Table 3 shows that the Durbin-Watson value is 1.766. The Durbin-Watson value from the table is obtained where $\mathrm{k}=3$ (number of independent variables) and $\mathrm{n}=72$ (number of observations) then the du value is 1.7054 . So, the DW value of 1.766 is greater than du, which is 1.7054 and less than $4-\mathrm{du}(4-1.7536=2.2946)$. If the value of $\mathrm{du}<\mathrm{dw}<4-\mathrm{du}(1.7054$ $<1.766<2,2946)$ then this result free from autocorrelation.

3.9 Glejser Test

Table 4. Test Results Glejser

\section{Coefficients $^{\mathrm{a}}$}

Model

Sig.

1

(Constant)

.380

LN_ROA

.144

LN_CR

LN_TATO

.068

a. Dependent Variable: RES2

Source: SPSS Output Results.

Based on table 4 it can be seen from the probability of its significance above the confidence level of $5 \%$ or 0.05 for all three variables. So it can be concluded that the regression model does not contain any heteroscedasticity.

\subsection{Determination Coefficient Test $\left(R^{2}\right)$}

The coefficient of determination $\left(\mathrm{R}^{2}\right)$ is basically used to measure or determine the magnitude of the influence of independent variables, namely ROA, CR and TATO on DER. This test is done by looking at the value of the coefficient of determination (Adjusted $R$ Square). Here are the results from testing the coefficient of determination: 
Table 5. Adjusted R Square

\begin{tabular}{|c|c|c|c|}
\hline \multicolumn{4}{|c|}{ Model Summary ${ }^{b}$} \\
\hline Model & $\mathrm{R}$ & R Square & Adjusted R Square \\
\hline 1 & $.671^{\mathrm{A}}$ & .427 & .451 \\
\hline \multicolumn{4}{|c|}{ a. Predictors: (Constant), LN_TATO, LN_CR, LN_ROA } \\
\hline \multicolumn{4}{|c|}{ b. Dependent Variable: LN_DER } \\
\hline
\end{tabular}

Source: Results of SPSS Output.

The Adjusted $R$ Square value indicates that value of $42.7 \%$ is caused by independen variables while the remaining $57.3 \%$ is caused by other factors not present in this research.

\subsection{Test Statistic $t$}

Table 6. Partial Significance Test Results (Test Statistics t)

\begin{tabular}{lllll}
\hline Coefficients $^{\mathbf{a}}$ & & & \\
\hline Model & & $\begin{array}{l}\text { Unstandardized } \\
\text { Coefficients }\end{array}$ & T & Sig. \\
& & & \\
& & & & \\
1 & (Constant) & -.597 & $-2,426$ & .018 \\
& LN_ROA & -.269 & $-3,587$ & .001 \\
& LN_CR -, & 532 & $-3,595$ & .001 \\
& LN_TATO & -.198 & -2.117 & .038 \\
a. Dependent Variable: LN_DER & & & \\
\hline
\end{tabular}

Source: SPSS Output Results.

Based on the above table can be explained as follows:

1) Based on table 6 shows that the ROA variable has a regression coefficient of -0.269 , meaning that the ROA variable has a negative effect on DER. The significance value of the ROA variable is $0.001<0.05$ so it can be concluded that $\mathrm{H} 1$ is accepted which states that ROA has a significant effect on DER.

2) Based on table 4.7 shows that the CR variable has a regression coefficient of -0.532 , meaning that the CR variable has a negative effect on DER. The significance value of the CR variable is $0.001<0.05$ so it can be concluded that $\mathrm{H} 2$ is accepted which states that $\mathrm{CR}$ has a significant effect on DER.

3) Based on table 4.7 shows that the TATO variable has a regression coefficient of -0.198 , meaning that the TATO variable has a negative effect on DER. The significance value of the TATO variable is $0.038<0.05$ so it can be concluded that $\mathrm{H} 3$ is accepted which states TATO has a significant influence on DER. 


\subsection{Test Statistic F}

Table 7. Test Statistic F

\begin{tabular}{llll}
\hline ANOVA $^{\text {a }}$ & & & \\
Model & & F & Sig. \\
\hline 1 & Regression & 18.607 & $.000^{\mathrm{b}}$ \\
& Residual & & \\
& Total & & \\
& \\
a. Dependent Variable: LN_DER & & \\
b. Predictors: (Constant), LN_TATO, LN_CR, LN_ROA &
\end{tabular}

Source: SPSS Output Results.

Based on Table 8 shows the calculated $\mathrm{F}$ value of 18.607 while $\mathrm{F}$ table at a significance level of $5 \%$ and df1 $(\mathrm{N} 1)=\mathrm{k}-1=4-1=3$, df2 $(\mathrm{N} 2)=72-3=69$, so F Table is 2.74 means F count $>\mathrm{F}$ table (18.607> 2.74), it can be concluded that the variable Return On Asset (X1), Current Ratio (X2), and Total Asset Turnover (X3) has a simultaneous effect on Debt to Equity Ratio (Y).

\subsection{Interpretation of the Results}

The results of the research indicate that Return on Asset has a negative and significant effect on capital structure. Negative results illustrate that the higher the company's profits, the company will reduce the proportion of debt usage in the company's capital structure.Companies in the Indonesia Stock Exchange prefer to use internal funding sources from retained earnings to finance their operations such as product development or the need for investment costs other than using sources and externally originating from parties outside the company. The decision was made by the company to minimize risk in the event of bankruptcy and large interest costs. This is also in accordance with the pecking order theory which states that a company with a high level of profitability will use low debt because the company will choose to use its internal resources in financing and operating the company. The results of this study are consistent with the research of Yusrianti (2013), Farisa and Widati (2017), as well as Dewiningrat and Mustanda (2018) which stated that Return On Asset had a significant negative effect on Debt Equity Ratio.

Current Ratio has a negative and significant relationship to capital structure. The results of the study show that the higher the level of liquidity of the company reduces the proportion of debt usage in the company's capital structure. Companies that have a high level of liquidity are able to pay off their short-term liabilities. This means that the company has enough internal funds so that the company tends to minimize the amount of debt or external funding sources which will make the composition of the capital structure lower. This is also because companies with high levels of liquidity prefer to use internal funding sources to finance new investments. The results of this study are in accordance with the research of Riasita (2014), Farisa and Widati (2017), as 
well as Dewiningrat and Mustanda (2018) which stated that CR had a significant negative effect on DER.

Total Asset Turnover (TATO) has a negative and significant effect on capital structure. The results of the study show that the higher the rate of turnover of a company's assets reduces the proportion of debt usage in the company's capital structure.

The high level of asset turnover of the company shows that the management of the company is increasingly effective in managing the assets owned to run the company's operations and produce high sales volumes as well. This also shows that the higher the turnover of the company's assets, the return in the most liquid form, namely the company's cash tends to be fast so that the company prefers to use internal funds for operational financing compared to the use of funds from external sources. The results of this study are in accordance with the study by Wardhana and Mawardi (2016) which stated that Total Asset Turn Over had a significant negative effect on Debt Equity Ratio.

\section{Conclusions and Recommendation}

After testing in this research, it can be concluded as follows:

1) ROA has a negative and significant effect on DER.

2) CR has a negative and significant effect on DER.

3) TATO has a negative and significant influence on DER.

\subsection{For Researchers}

For researcher for the next research able to add other variables such as company size, asset structure, dividend policy, and sales growth.

\subsection{For Company}

For the company to conduct business expansion and operational financing of companies, then the source of funds using a pecking order theory is with retained earnings first, then share emissions, and finally by using debt.

\section{References}

Arsyad, Lincoln dan Soeratno. (2003). Metode Penelitian untuk Ekonomi dan Bisnis. Edisi Revisi. Yogyakarta: UPP YKPN.

Dewiningrat, Ayu Indira dan I Ketut Mustanda. (2018). Pengaruh Likuiditas, Profitabilitas, Pertumbuhan Penjualan dan Struktur Aset Terhadap Struktur Modal. E-Jurnal Manajemen Unud, 07(07).

Farisa, Nurul Anggun dan Listyorini Wahyu Widati. (2017). Analisa Profitabilitas, Likuiditas, Pertumbuhan Penjualan, Struktur Aktiva dan Kebijakan Dividen Terhadap Struktur Modal. Program Studi Akuntansi FEB Universitas Stikubank.

Ghozali, I. (2013). Aplikasi Analisis Multivariate Dengan Program IBM SPSS 21. Semarang: Badan Penerbit Universitas Diponegoro.

Hanafi, Mamduh M dan Abdul Halim. (2009). Analisis Laporan Keuangan. Yogyakarta: UPP STIM YPKN.

Kasmir. (2012). Analisis Laporan Keuangan. Rajawali pers. Jakarta.

Malhotra, N. K. (2005). Riset Pemasaran. Jakarta: PT. Indeks. 
Margaretha, F., dan Aditya Rizky Ramadhan. (2010). Faktor-Faktor yang Mempengaruhi Struktur Modal pada Industri Manufaktur di Bursa Efek Indonesia. Jurnal Bisnis dan Akuntansi, 12(2), 119-130.

Myers, S. (1984). The Capital Structure Puzle. Journal of Finance, 39. https://doi.org/10.2307/2327916

Riasita, D. (2014). Pengaruh Profitabilitas, Likuiditas, Pertumbuhan Aktiva, Struktur Aktiva dan Ukuran Perusahaan Terhadap Struktur Modal Pada Perusahaan Manufaktur Di Bursa Efek Indonesia Periode 2009-2013.

Riyanto, B. (2010). Dasar-dasar Pembelanjaan Perusahaan. Yogyakarta: BPFE-UGM

Riyanto, B. (2001). Dasar-dasar Pembelanjaan Perusahaan. Yogyakarta: BPFE -Yogyakarta.

Sudana, I. M. (2011). Manajemen Keuangan Teori dan Praktik. Surabaya: Airlangga University Press

Sudana, I. M. (2015). Manajemen Keuangan Teori dan Praktik. Surabaya: Penerbit Airlangga

Suharsimi, A. (2006). Prosedur Penelitian : Suatu Pendekatan Praktek. Jakarta: PT. Rineka Cipta.

Usman, Husaini dan Purnomo Setiady A. (2006). Pengantar Statistika. Edisi Kedua. Jakarta: PT. Bumi Aksara.

Wardhana, Iga Bagus Jaya dan Wisnu Mawardi. (2016). Analisis Pengaruh Struktur Aktiva, Asset Turnover, Growth Terhadap Profitability Melalui Variabel Capital Structure Sebagai Variabel Intervening (Studi Kasus pada Perusahaan Consumer Goods BEI Periode Tahun 2012-2014). Diponegoro Journal of Management, 5(2), 1-14.

Watung, Abraham Kelli Sion, Ivonne S Saerang. Pengaruh Rasio Likuiditas, Profitabilitas, dan Struktur Aktiva Terhadap Struktur Modal Industri Barang Konsumsi Di Bursa Efek Indonesia. Jurnal Emba, 4(2).

Yusrianti, H. (2013). Pengaruh Tingkat Profitabilitas, Struktur Asset Dan Growth Opportunity Terhadap Struktur Modal Pada Perusahaan Manufaktur yang Telah Go Public Di Bursa Efek Indonesia.

\section{Copyright Disclaimer}

Copyright for this article is retained by the author(s), with first publication rights granted to the journal.

This is an open-access article distributed under the terms and conditions of the Creative Commons Attribution license (http://creativecommons.org/licenses/by/3.0/). 